Apparatus Manufacturers' Association, the Scientific Instrument Manufacturers' Association, the Scientific Instrument Research Association, and the United Kingdom Automation Council. The work of the British Standards Institution, with its many standards and excellent codes of practice, conceived and executed in close cooperation with these various bodies, is a vital part of this elosely knit organization, and is rightly acknowledged in this informative publication.

\section{Cerebrovascular Accidents}

THE booklet entitled Cerebrovascular Accidents as a Public Health Problem-Selected Recent Abstracts II, is the second of two publications on this important subject which are issued free from the School of Hygiene and Public Health, Johns Hopkins University (Pp. 64. Baltimore, Md.: Research in Public Hoalth Administration Project, School of Hygiene and Public Health, Johns Hopkins University, 1965). It provides abstracts of recent papers by numerous authors on this disease and on problems related to it. After an introduction by Prof. C. M. Wylie, successive chapters doal with problems of diagnosis, epidemiology and statistics, preventive aspects, and medical and surgical care. The main aim of the booklet is to help readers to find original papers which they may have overlooked, and both Abstracts I and II should be valuable to everyone who is interested in advances in knowledge of these afflictions, or who is in any way associated with their practical care. Publication of the booklet has been financed by a grant from the W. K. Kellogg Foundation.

\section{Aquatic Microbiology Group}

A NUMBer of workers engaged in various fields of aquatic microbiology have for some time felt that it would be well worth while to call into being an informal aquatic microbiologists group. Such a group would be useful for the interchange of ideas and for a discussion of the problems encountered in this field. The autumn meeting of the Society for General Microbiology held in Aberdeen, on September 16-18, included a symposium on marine microbiology, and afforded an obvious opportunity to convene such a group. Accordingly, the group met for the first time at Torry Research Station, with Dr. Lucas, director of the Marine Laboratory of the Departmont of Agriculture and Fisheries for Scotland, in the chair. The meeting was entirely informal and was concerned more with work in progress, or with problems facing workers in this field, than with the accounts of completed work which are presented at the familiar formal scientific meeting. The first discussion was concerned with sea-water as a culture medium, and reference was made particularly to the suspended matter found in natural waters, which microbiologists usually remove when making their media. It was suggested that by so doing they changed the physical and chemical environment sufficiently to prevent some organisms from growing, and that by leaving the suspended matter in the medium it may be possible to culture certain micro-organisms that cannot, at the moment, be cultured by traditional techniques. The second discussion dealt with the 'dark growth' of certain phototrophic algae which also have the ability to grow heterotrophically in the dark. Much of the discussion was concerned with the interpretation of saturation constants and doubling times found for a number of algae and bacteria under various exporimental conditions. 'These suggest that in the natural environment the bacteria would soon outstrip the algae in the utilization of the available nutrients. Possible mechanisms to explain these phenomena were put forward and examined. The third session was devoted to an account of the work, now in progress in various laboratories, on the bactericidal offect of light on Escherichia coli in sea-water. This led to a more goneral discussion of the effects of light in the visible range of bacteria, and on the possible protective effect of carotenoid pigments. At the end of the discussion it was decided that further meetings of a similar type should be convened, the first to be held in about a year.

\section{Fertilizer Corporation of India, Ltd.}

The Planning and Development Division of the Fertilizer Corporation of India, Ltd., publishes a quarterly bulletin entitled Technology, which is concerned with both academic and practical problems in the expanding field of fertilizer production and use. The contents of a recent issue indicate the scope of this journal (Technology, 2, No. 1; January-March 1965. Pp. 69, including separate subject index, Vol. 1, January-Docember 1964. Fertilizer Corporation of India, Ltd., Sindri, Bihar). Tho chief subjects discussed are: X-ray study of calcium ammonium nitrate, by S. K. Ghosh, V. K. Srinivasa and B. K. Banorjee; physical investigation of calcium ammonium nitrate, by S. Mukherjee, M. Samaddar and H. Roy; removal of nitrogen from fertilizer factory effluent by biochemical nitrification and denitrification, by A. C. Das, J. A. Khan and B. K. Dutta; trivalent arsenic compound as an inhibitor of corrosion of stainless steel in sulphuric acid, by A. K. Roy and K. M. Verma; extraction and estimation of humic and fulvic acids from soil and their fractionation by paper chromatography, by A. Sinha and R. N. Shukla; use of air from a nitric acid turbo-compressor for de-riming cold boxes in air-liquefaction units of an ammonia plant, by B. S. Kalia and C. L. Kaul; bulk blending and compatibility of fertilizers, by S. Varma; and reprography, by M. R. Roy. The subjects of short communications range from solubility of arsenic trioxide in aqueous ammonia at $40^{\circ}$ and $50^{\circ} \mathrm{C}$, desensitizers for ammonium nitrate, determination of total pyridines and quinolines in ammoniacal liquor by ultra-violet spectro. photometry, to testing of gas-mask canisters. Other features of this bulletin are technical digests, notes, news and statistics.

\section{Organo-mineral Complex in Soils}

THe complex of mineral and organic matter in soils has been intensively investigated both by chemists and by biologists. The problem presents great difficulties, since the organic matter is of complex constitution and the surfaces of the mineral matter vary from those of relatively well-reeognized micro-erystalline clay minerals to those of amorphous oxides and hydroxides. A liberally documented review of present knowledge, entitled "Inter. action between Clays and Organic Compounds in Soils". Part 1: "Mechanisms of Interaction between Clays and Defined Organic Compounds", by D. J. Greenland, is presented in Soils and Fertilizers $(28$, No. 5, 415; 1965). Free organic material may be separated from weakly bonded material by flotation techniques in liquids of suitable density $(1 \cdot 8-2 \cdot 0)$ following satisfactory dispersion. Except in very sandy soils, most of the total organic matter is bonded with inorganic material, the uncombined fraction being in an early stage of decompositionthe bulk of humic acids, for example, seems to be present in the complex. It would also appear that the clay-size mineral matter is mainly associated with the complex, while sand and silt are mainly 'free'. The forces concerned in the interaction may be Coulombie attractions, or Van der Waals forces, but there may bo a large number of major and minor interactions between different parts of the surface of the mineral and the organic molecule. The relative importance of the various processes has becn investigated by measuring the adsorption of well-defined organic compounds by montmorillonite, elays with mica. type lattices, kaolinite, and oxides. In general, organic compounds of molecular weight less than 150 are not adsorbed unless they can take part in ion-exchange, but larger molecules, with or without a charge, may compets. 